\title{
Role of Integrated Information Technology for Responses to Violence Against Women and Children During Covid-19 Pandemic
}

\section{Zeinab Mohammadzadeh}

Tabriz University of Medical Sciences

Elham Maserat ( $\nabla$ E.maserat@modares.ac.ir)

Tarbiat Modares University

\section{Research Article}

Keywords: Covid-19, Domestic Violence, Child abuse, Abused Women, E-health

Posted Date: October 13th, 2021

DOI: https://doi.org/10.21203/rs.3.rs-909415/v1

License: (c) (i) This work is licensed under a Creative Commons Attribution 4.0 International License. Read Full License 


\section{Abstract}

Background: The restriction and quarantine due to Covid-19 has led to unprecedented disruptions in the lives of women and children. Due to the increase in violence against women and children, the using of e-health has been considered to provide supportive care in this area. The purpose of this paper is developing comprehensive evidencebased framework of e-health intervention to response women and child violence.

Methods: The methodology of this study was based on a two-stage which included literature review at the beginning. In first step a comprehensive review performed for extracting studies that survey the effectiveness of information technology in managing violence against women and child. Researches extracted appropriate articles and summarized important component. The review steps included set questions, search strategy and inclusion/exclusion criteria. The framework was defined based on the literature review and social-ecological model (SEM).

Result: The finalized framework for application IT-based interventions in the management of violence against women and children presented in 4 dimension including individual, relationship, community and societal. The first and second levels of this model include 4 dimensions of SEM and 6 types of violence. The third level includes suggestions for managing violence and the fourth level includes IT-based interventions. Surveillance system and information resource system can be used for monitoring

Conclusion: During Covid-19, domestic violence and economic pressures increased, and vulnerable women and children were at greater risk. It is critical to identify people at risk, to follow and monitor them, to raise the awareness and knowledge of these people, and to empower and provide psychosocial support to these people during this period. In this study, a comprehensive review of IT-based interventions was presented and finally an international framework in this field was described.

\section{Background}

According to WHO reports, globally, 31\% of women aged 15-49 (almost one in every three women) experience physical and/or sexual intimate partner violence (IPV) or non-partner sexual violence (NPSV) or both in their lifetime (1). The Centers for Disease Control and Prevention identifies four IPV type including physical violence, sexual violence, stalking and psychological aggression (2). The United Nations (UN) defines violence against women as "any act of gender-based violence that results in, or is likely to result in, physical, sexual, or mental harm or suffering to women, including threats of such acts, coercion or arbitrary deprivation of liberty, whether occurring in public or in private life" (3). Gender based violence has increased due to restrictions on the Covid-19 pandemic(4). During this pandemic, there were reports of increased violence against partners (5).

Also children experienced different psychological and physical abuse (6). In many countries, the report of violencerelated cases has increased in calls to emergency support lines (7).Child maltreatment defined by WHO as abuse and neglect that occurs to children under 18 years of age. WHO divided child abuse to neglect, physical abuse, sexual abuse, emotional abuse. WHO statistics show $22.6 \%$ of child e suffered from physical abuse. This statistics for emotional abuse and physical neglect are respectively $36.3 \%$ and $16.3 \%$ (8). Reports about prevalence of violence shows that a minimum of $50 \%$ of children in Asia, Africa, and Northern America have experienced violence (9). Child maltreatment has many consequences for the child, family and community such as physical and mental problems, disorders in future life and social activity, scientific development, and reproductive health $(10,11)$.

Also with the outbreak of the epidemic, various strategies were offered to control it, such as quarantine, isolating suspected individuals, national lockdown, Working remotely, etc $(12,13)$. The restriction and quarantine due to Covid- 
19 pandemic have led to increased financial and psychological problems for some people (14). The Covid-19 has led to unprecedented disruptions in the lives of women and children $(15,16)$. Along with other economic and social initiatives, the WHO has emphasized respecting human rights during this epidemic (4). The WHO has also insists that countries should develop programs and plans in national and international levels to health service delivery for affected peoples and prevent violence (17). According to WHO guidelines, women who experience such violence need immediate interventions to improve their emotional/psychological and physical health (18). Policy makers should aware violence and develop evidence-based interventions to meet the psychological needs of children, women and their families during this epidemic (19). The WHO has developed clinical and policy guidelines for this purpose entitled responding to intimate partner violence and sexual violence against women (20). Some online tools developed to educate provider for presenting support practices and programs including EDUCATE program, REAL Talk and Domestic Violence Education Program (21).

An online platform to recognize and respond to family violence including child maltreatment and intimate partner violence is VEGA (Violence, Evidence, Guidance, and Action) Project. This platform helps healthcare providers to better caring for clients who have experienced family violence (22). Other Evidence-based recommendations for recognizing and responding to IPV are guidelines of WHO (20), NICE (National Institute for Health and Care Excellence), Futures Without Violence and National Health Service (23).

Due to the increase in violence against women and children, the using of telehealth has been considered to provide supportive care in this area. In recent years, many studies have examined the effectiveness of IT tools in providing psychosocial services to different target groups (24). With the advent of Covid-19, the use of telehealth approaches increased significantly to provide behavioral health services $(12,25)$. Managing violence against women and children is a serious challenge for both patients and service providers. And IT-based tools can be used to help both. Telehealth

provide remotely and interactive care through video conferencing. It can be synchronous and asynchronous (26). The purpose of this study is to review information technology (IT)-based interventions in the management of violence against women and children. In continue a comprehensive evidence-based framework of e-health was developed to response this issue.

\section{Methodology}

The methodology of this study was based on a two-stage which included literature review at the beginning. In first step a comprehensive review performed for extracting studies that examine the effectiveness of telehealth technology in managing violence against women and child. The authors extracted appropriate articles and summarized important component in table 1 and 2. The review steps included set questions, search strategy and inclusion/exclusion criteria. Searches were developed in August and September 2021. Based on the literature review, the framework was defined.

\section{Inclusion Criteria}

Only articles included that implemented an intervention to violence management in women \& child and either outcome. At this stage, all the telehealth technologies were included without any restrictions. Studies searched without time limitation. After screening title and abstract full-text were reviewed. Articles were included If reported intervention and its effect.

\section{First step: initial literature study}


The search was conducted in the Cochrane Library, Scopus, Embase, ProQuest, PubMed and Google Scholar (the first 10 pages). The keywords for women scope including violence AND domestic violence AND intimate partner violence AND (medical informatics OR telehealth OR telephone OR telemedicine OR social media OR internet OR telemedicine OR email OR geographic information systems OR electronic health OR registry).

The keywords for child scope including (child abuse OR physical abuse OR sexual abuse OR emotional abuse OR neglect) AND (medical informatics OR telehealth OR telephone OR telemedicine OR social media OR internet OR telemedicine OR email OR geographic information systems OR electronic health OR registry). Then articles that used various telehealth tools in response to violence against women and children as an intervention were extracted based on title and abstract. The websites of leading organizations in this field was reviewed, such as the World Health Organization (WHO).

\section{Data Extraction}

Two independent researchers reviewed all documents separately to identify eligible studies. Then reports excluded if did not meet the inclusion criteria. Data of included documents entered in to the data collection forms. The disagreements between reviewers were addressed by group discussions. Two reviewers extracted the data from the full text and summarized in the form of a table including setting, purpose, intervention, method (number of target population, study type, length of intervention, duration and follow-up) and result of intervention were determined.

\section{Second step: framework development}

According to the result of initial literature review, the framework to response violence against women and child based on IT tools were formulated and designed. In this step, IT interventions related to five types of physical, psychological, economic, sexual and cyber violence were investigated. Violence management were assessed in four levels of socialecological model (SEM). Social-ecological model (SEM) is used as a framework for violence prevention that has four levels (27). The four levels of this model include individual (Woman \& Child), relationship, community and societal levels (28). In this study, SEM model was used to provide a platform for IT-based interventions during the Covid-19 pandemic to prevent violence against children and women.

\section{Result}

\section{Review of literature in the field of IT tools application in response violence against women and child}

In this study, all relevant literature in the field of IT tools application in response violence against women and child were reviewed. Then a framework was designed based on information of first step as well as WHO and other organization guidelines. Tables 1 and 2 summarize the result of literature review.

Table 1: Summary of studies in the field of IT tools interventions in managing child abuse 


\begin{tabular}{|c|c|c|}
\hline Author & Setting & Purpose \\
\hline $\begin{array}{l}\text { Dursun et } \\
\text { al. (2021) } \\
\text { (16) }\end{array}$ & Turkey & $\begin{array}{l}\text { To develop tele } \\
\text { psychiatry } \\
\text { application to } \\
\text { Health Care } \\
\text { Workers and Their } \\
\text { Children During } \\
\text { COVID-19 } \\
\text { Pandemics }\end{array}$ \\
\hline
\end{tabular}

Intervention

A mobile application

that developed by the

Ministry of Health and

available in mobile

stores.
Method

- Pre-post

- N: 1,076

(child \& adult)

- Video calls contact \& If necessary, face to face psychiatric evaluation

\begin{tabular}{|c|c|c|}
\hline $\begin{array}{l}\text { Obikane et } \\
\text { al. (2021) } \\
(29)\end{array}$ & Japan & $\begin{array}{l}\text { Prevent child abuse } \\
\text { with } \\
\text { improving postnatal } \\
\text { depression by web- } \\
\text { based program }\end{array}$ \\
\hline
\end{tabular}

internet-based

behavioral activation

(iBA) therapy

\section{- RCT \\ - Improved maternal \\ $-N=390$ Two \\ - Intervention group \\ - Duration: 12 weekly iBA sessions Follow up: 24 weeks}

\begin{tabular}{lll}
$\begin{array}{l}\text { Gülırmak } \\
\text { et al. } \\
(2021)(30)\end{array}$ & Turkey & $\begin{array}{l}\text { Determine the } \\
\text { effectiveness of } \\
\text { web-based } \\
\text { education for } \\
\text { prevention of child } \\
\text { abuse }\end{array}$ \\
& & \\
\hline $\begin{array}{l}\text { Traube et } \\
\text { al.(2020) } \\
(31)\end{array}$ & USA & $\begin{array}{l}\text { development of } \\
\text { Parents as } \\
\text { Teachers @ USC } \\
\text { Telehealth }\end{array}$
\end{tabular}

$\begin{array}{lll}\begin{array}{l}\text { Web-based distance } \\ \text { education- Website }\end{array} & \begin{array}{l}\text { - Quasi- } \\ \text { experimental, } \\ \text { randomized } \\ \text { controlled }\end{array} & \begin{array}{l}\text { - Effectiveness } \\ \text { in awareness } \\ \text { of emotional }\end{array} \\ \begin{array}{ll}\text { (http:// } \\ \text { farkindaebeveynler.com) }\end{array} & \begin{array}{l}\text { abuse in the } \\ \text { experimental } \\ \text { group }\end{array} \\ & \begin{array}{ll}\mathrm{N}=60 \text { parents } \\ \text { - Duration: 6- } \\ \text { week }\end{array} & \end{array}$

Home-based parenting programs via interactive Experimental video conferencing
- Parent satisfaction of program

- Duration: 5 month - 11 personal visits.

- High improve in parental supervision

\begin{tabular}{|c|c|c|}
\hline $\begin{array}{l}\text { Fogler et } \\
\text { al. } \\
\text { (2020) (32) }\end{array}$ & USA & $\begin{array}{l}\text { Evaluating } \\
\text { acceptability and } \\
\text { feasibility of } \\
\text { telepsychology to } \\
\text { parent training with } \\
\text { high quality }\end{array}$ \\
\hline
\end{tabular}

Telepsychology BCADHD

\section{- Open Trial}

$-\mathrm{N}=20$

\section{- Approved acceptability and feasibility of telepsychology to parent training with high quality.}

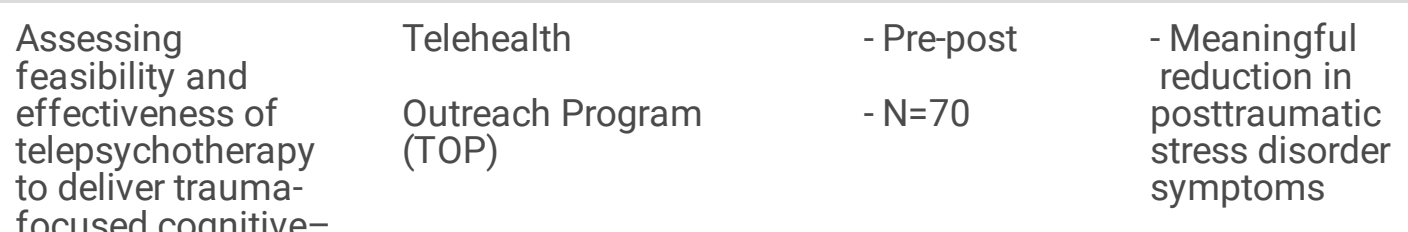

\begin{abstract}
al.
\end{abstract}
(2020) (33)
Assessing

USA

focused cognitive-

behavioral therapy 


\begin{tabular}{|c|c|c|c|c|c|}
\hline Author & Setting & Purpose & Intervention & Method & Result \\
\hline $\begin{array}{l}\text { Luo et al. } \\
(2020) \text { (34) }\end{array}$ & USA & $\begin{array}{l}\text { Evaluation of the } \\
\text { usability and } \\
\text { acceptability of a } \\
\text { mobile application }\end{array}$ & $\begin{array}{l}\text { Mobile application } \\
\text { called sexual as-sault } \\
\text { care algorithm (SACA }\end{array}$ & $\begin{array}{l}\text { Mixed } \\
\text { methods } \\
\mathrm{N}=4 \text { ( SANE) }\end{array}$ & $\begin{array}{l}\text { - High } \\
\text { usability and } \\
\text { acceptability } \\
\text { - Effective in } \\
\text { performing } \\
\text { tasks and } \\
\text { helping to } \\
\text { make } \\
\text { decisions }\end{array}$ \\
\hline $\begin{array}{l}\text { van } \\
\text { Rosmalen- } \\
\text { Nooijens et } \\
\text { al. } \\
(2017)(35)\end{array}$ & Netherlands & $\begin{array}{l}\text { Assessing } \\
\text { effectiveness and } \\
\text { feasibility of the } \\
\text { Internet-based self- } \\
\text { support method } \\
\text { "Feel the ViBe" (FtV) }\end{array}$ & $\begin{array}{l}\text { Feel the ViBe (FtV) ( } \\
\text { Internet-based self- } \\
\text { support method) }\end{array}$ & $\begin{array}{l}\text { - RCT } \\
\text { - Intervention } \\
\text { group: access } \\
\text { to FtV + usual } \\
\text { care } \\
\text { - RCT } \\
\text { - N=40 } \\
\text { - Data } \\
\text { collection: at } \\
\text { baseline and } \\
\text { every } 6 \text { weeks } \\
\text { until } 24 \\
\text { weeks }\end{array}$ & $\begin{array}{l}\text { - no significant } \\
\text { change in } \\
\text { impact of } \\
\text { Event Scale } \\
\text { - Significant } \\
\text { improvements } \\
\text { in } \\
\text { depression \& } \\
\text { anxiety }\end{array}$ \\
\hline
\end{tabular}

ADHD = Attention-Deficit/Hyperactivity Disorder

BC: Bootcamp

RCT: Randomized-Controlled Trial

SANE: Sexual Assault Nurse Examiners

Table 2: Summary of studies in the field of IT tools interventions in response violence against women 


\begin{tabular}{|c|c|c|c|c|}
\hline Author & Setting & Purpose & Intervention & Method \\
\hline \multirow{5}{*}{$\begin{array}{l}\text { The EDUCATE } \\
\text { Investigators } \\
\text { (36) (2018) }\end{array}$} & \multirow{5}{*}{$\begin{array}{l}\text { Canada } \\
\& \text { USA }\end{array}$} & \multirow{5}{*}{$\begin{array}{l}\text { Measuring } \\
\text { impact of IPV } \\
\text { educational } \\
\text { program on } \\
\text { participant } \\
\text { readiness to } \\
\text { manage IPV. }\end{array}$} & \multirow{5}{*}{$\begin{array}{l}\text { 2-hour } \\
\text { educational } \\
\text { program } \\
\text { including (1) an } \\
\text { introductory } \\
\text { video, (2) } 3 \\
\text { online modules } \\
\text { and (3) an in- } \\
\text { person training } \\
\text { session led by } \\
\text { the local IPV } \\
\text { champion(s) }\end{array}$} & \\
\hline & & & & - N: 140 participants \\
\hline & & & & clinics $(6$ fracture \\
\hline & & & & $\begin{array}{l}\text { clinics in Canada } \\
\text { and } 1 \text { in the United } \\
\text { States) }\end{array}$ \\
\hline & & & & $\begin{array}{l}\text { - Data gathering: } \\
\text { immediate and } 3 \\
\text { months after intake }\end{array}$ \\
\hline
\end{tabular}

Result

- Significant

improvements on

10 subscales

including actual

knowledge,

perceived

preparation,

perceived

knowledge,

practice issues,

preparation, legal

requirements,

workplace issues,

self-efficacy,

alcohol/drug and

victim

understanding.

Walsh et

al. (37) (2019)
USA

Assessing Patient
Consent for
Telehealth,
Effectiveness of
Technology and
Types of
Assistance
Provided

Live sexual assault nurse examiner (SANE)

services via

telehealth

(teleSANEs) for

adult

and adolescent

patients
- Descriptive study - High levels of

$-N=215$

- Sites: six pilot sites

consent

- Proper system

effectiveness

- Positive impact

of the assistance

including

guiding clinicians

through history

taking and

documentation,

forensic

examination and

evidence

collection

techniques,

identifying and

documenting

injuries, and

guiding clinical

practice. 


\begin{tabular}{|c|c|c|c|c|c|}
\hline Author & Setting & Purpose & Intervention & Method & Result \\
\hline \multirow{7}{*}{$\begin{array}{l}\text { Hegarty et al. } \\
(2019) \text { (38) }\end{array}$} & \multirow[t]{7}{*}{ Australia } & \multirow{7}{*}{$\begin{array}{l}\text { Assessing effect } \\
\text { of I-DECIDE in } \\
\text { self-efficacy and } \\
\text { depressive } \\
\text { symptoms }\end{array}$} & \multirow{7}{*}{$\begin{array}{l}\text { Website: An } \\
\text { online interactive } \\
\text { healthy } \\
\text { relationship tool } \\
\text { and safety } \\
\text { decision aid (I- } \\
\text { DECIDE) }\end{array}$} & - RCT & \multirow{7}{*}{$\begin{array}{l}\text { - No meaningful } \\
\text { differences } \\
\text { between groups in } \\
\text { self-efficacy } \\
\text { and depressive } \\
\text { symptoms }\end{array}$} \\
\hline & & & & $-\mathrm{N}: 422$ & \\
\hline & & & & & \\
\hline & & & & $\begin{array}{l}\text { healthy } \\
\text { relationships, abuse } \\
\text { and safety, and } \\
\text { relationship priority } \\
\text { setting, and a } \\
\text { tailored action plan }\end{array}$ & \\
\hline & & & & $\begin{array}{l}\text { - Control website: } \\
\text { static IPV } \\
\text { information }\end{array}$ & \\
\hline & & & & $\begin{array}{l}\text { - Length of follow- } \\
\text { up: 6-month and } \\
\text { 12-month }\end{array}$ & \\
\hline & & & & $\begin{array}{l}\text { - Data gathering: at } \\
\text { baseline, } 6 \text { and } 12 \\
\text { months }\end{array}$ & \\
\hline \multirow{4}{*}{$\begin{array}{l}\text { Sabri et al. } \\
\text { (2019) (39) }\end{array}$} & \multirow[t]{4}{*}{ USA } & \multirow{4}{*}{$\begin{array}{l}\text { Assessing the } \\
\text { effectiveness of } \\
\text { intervention on } \\
\text { safety, mental } \\
\text { health and } \\
\text { empowerment }\end{array}$} & \multirow{4}{*}{$\begin{array}{l}\text { Web-based } \\
\text { safety decision } \\
\text { aid/safety } \\
\text { planning } \\
\text { (myPlan): } \\
\text { weWomen and } \\
\text { ourCircle }\end{array}$} & $-\mathrm{RCT}$ & \multirow[t]{4}{*}{ NA } \\
\hline & & & & $-\mathrm{N}: 1,250$ & \\
\hline & & & & $\begin{array}{l}\text { - Length of follow- } \\
\text { up:1 year }\end{array}$ & \\
\hline & & & & $\begin{array}{l}\text { - Data gathering: at } \\
\text { baseline, 3, } 6 \text { and } \\
12 \text { months }\end{array}$ & \\
\hline \multirow{3}{*}{$\begin{array}{l}\text { Ford-Gilboe et } \\
\text { al. } \\
(2017) .(40)\end{array}$} & \multirow[t]{3}{*}{ Canada } & \multirow{3}{*}{$\begin{array}{l}\text { Assessing } \\
\text { effectiveness of } \\
\text { iCAN in } \\
\text { improving the } \\
\text { health and safety } \\
\text { for women } \\
\text { experiencing IPV }\end{array}$} & \multirow{3}{*}{$\begin{array}{l}\text { iCAN Plan } 4 \\
\text { Safety (a } \\
\text { tailored, online } \\
\text { safety and } \\
\text { health } \\
\text { intervention) }\end{array}$} & $-\mathrm{RCT}$ & \multirow{3}{*}{$\begin{array}{l}\text { - Effective in } \\
\text { managing } \\
\text { depression and } \\
\text { PTSD symptoms }\end{array}$} \\
\hline & & & & $-N=450$ & \\
\hline & & & & $\begin{array}{l}\text { - Length of follow- } \\
\text { up: } 1 \mathrm{Y}\end{array}$ & \\
\hline
\end{tabular}




\begin{tabular}{|c|c|c|c|c|c|}
\hline Author & Setting & Purpose & Intervention & Method & Result \\
\hline $\begin{array}{l}\text { Steinmetz et } \\
\text { al.(41)(2016) }\end{array}$ & USA & $\begin{array}{l}\text { Providing } \\
\text { individual therapy } \\
\text { to survivors of } \\
\text { sexual assault } \\
\text { and domestic } \\
\text { violence in rural } \\
\text { areas }\end{array}$ & Videoconference & $\begin{array}{l}\text { - Pre-post } \\
\text { - Developed by } \\
\text { The Wyoming } \\
\text { Trauma } \\
\text { Telehealth } \\
\text { Treatment } \\
\text { Clinic (WTTTC) } \\
\text { - Session } \\
\text { number: six or } \\
\text { more } \\
\text { sessions took } \\
\text { place weekly } \\
\text { - Trauma- } \\
\text { focused } \\
\text { therapy } \\
\text { - Duration: 60- } \\
\text { 90 min } \\
\text { - Measuring } \\
\text { PTSD, } \\
\text { depression, and } \\
\text { satisfaction of } \\
\text { sample in } \\
\text { pretreatment } \\
\text { and post } \\
\text { treatment }\end{array}$ & $\begin{array}{l}\text { - Meaningful } \\
\text { decrease in } \\
\text { PTSD } \\
\text { symptoms } \\
\text { - Reduction in } \\
\text { depressive } \\
\text { symptoms } \\
\text { - high levels of } \\
\text { satisfaction }\end{array}$ \\
\hline
\end{tabular}

\begin{tabular}{|c|c|c|c|}
\hline $\begin{array}{l}\text { Constantino } \\
\text { et al. (2015) } \\
\text { (42) }\end{array}$ & USA & $\begin{array}{l}\text { Assessing the } \\
\text { effectiveness of } \\
\text { the HELPP } \\
\text { among IPV } \\
\text { survivors }\end{array}$ & $\begin{array}{l}\text { Online HELPP } \\
\text { (Health, } \\
\text { Education on } \\
\text { Safety, and Legal } \\
\text { Support and } \\
\text { Resources in IPV } \\
\text { Participant } \\
\text { Preferred) }\end{array}$ \\
\hline
\end{tabular}




\begin{tabular}{|c|c|c|c|c|c|}
\hline Author & Setting & Purpose & Intervention & Method & Result \\
\hline $\begin{array}{l}\text { Saftlas et } \\
\text { al.(2010)(44) }\end{array}$ & USA & $\begin{array}{l}\text { Evaluating } \\
\text { effectiveness of } \\
\text { motivational } \\
\text { interviewing (MI) } \\
\text { self-efficacy, } \\
\text { stage-of- } \\
\text { readiness-to- } \\
\text { change, and } \\
\text { depressive } \\
\text { symptoms } \\
\text { among women in } \\
\text { abusive } \\
\text { relationships }\end{array}$ & Telephone calls & $\begin{array}{l}\text { - RCT } \\
\text { - N=204 } \\
\text {-Intervention group: } \\
\text { initial face-to-face } \\
\text { session and three } \\
\text { telephone sessions } \\
\text { (1-,2-, and 4-months } \\
\text { post enrollment) }\end{array}$ & $\begin{array}{l}\text { - Decrease in } \\
\text { depressive } \\
\text { symptoms } \\
\text { decreased } \\
\text { - No significant } \\
\text { difference } \\
\text { between the } \\
\text { control and } \\
\text { intervention } \\
\text { groups in Self- } \\
\text { efficacy and } \\
\text { stage-of- } \\
\text { readiness-to- } \\
\text { change } \\
\text { increasing. }\end{array}$ \\
\hline $\begin{array}{l}\text { Tiwari et } \\
\text { al. (45) (2012) }\end{array}$ & China & $\begin{array}{l}\text { Measuring } \\
\text { effectiveness of } \\
\text { advocacy } \\
\text { intervention for } \\
\text { women } \\
\text { experiencing IPV }\end{array}$ & $\begin{array}{l}\text { telephone social } \\
\text { support }\end{array}$ & $\begin{array}{l}\text { - RCT } \\
\text { - N= } 200 \\
\text { - Duration of } \\
\text { telephone calls: } 30 \\
\text { min } \\
\text { - Intervention group: } \\
12 \text { weekly } \\
\text { telephone calls and } \\
\text { 24-hour access to a } \\
\text { hotline } \\
\text { - Data gathering: } \\
\text { baseline, } 3 \text { months } \\
\text { and at } 9 \text { months } \\
\text { after intake }\end{array}$ & $\begin{array}{l}\text { - Reduction in } \\
\text { depression and } \\
\text { psychological } \\
\text { aggression, } \\
\text { improvement in } \\
\text { perceived social } \\
\text { support and the } \\
\text { use of safety- } \\
\text { promoting } \\
\text { behaviors }\end{array}$ \\
\hline $\begin{array}{l}\text { Tiwari et al. } \\
(2009)(46)\end{array}$ & China & $\begin{array}{l}\text { Measuring } \\
\text { effectiveness of } \\
\text { advocacy } \\
\text { intervention for } \\
\text { women } \\
\text { experiencing IPV }\end{array}$ & $\begin{array}{l}\text { telephone social } \\
\text { support }\end{array}$ & $\begin{array}{l}\text { - RCT } \\
\text { - N= } 200 \\
\text { - Duration of } \\
\text { telephone calls: } \\
\text { between } 15 \text { and } 20 \\
\text { minutes } \\
\text { - Intervention group: } \\
\text { advocacy } \\
\text { intervention and } \\
\text { telephone social } \\
\text { support at the } \\
\text { beginning of the } \\
\text { intervention } \\
\text { - Data gathering: at } \\
\text { baseline, } 3 \text { and } 9 \\
\text { months after intake }\end{array}$ & $\begin{array}{l}\text { - Positive } \\
\text { change in } \\
\text { quality of life } \\
\text { and perceived } \\
\text { social } \\
\text { support } \\
\text { - No significant } \\
\text { difference in } \\
\text { reducing the } \\
\text { depressive } \\
\text { symptoms. }\end{array}$ \\
\hline
\end{tabular}




\begin{tabular}{|c|c|c|c|c|c|}
\hline Author & Setting & Purpose & Intervention & Method & Result \\
\hline $\begin{array}{l}\text { Koziol-McLain } \\
\text { et al. (2018) } \\
\text { (47) }\end{array}$ & $\begin{array}{l}\text { New } \\
\text { Zealand }\end{array}$ & $\begin{array}{l}\text { Measuring } \\
\text { effectiveness of a } \\
\text { Web-based safety } \\
\text { decision aid } \\
\text { (isafe) for women } \\
\text { experiencing IPV }\end{array}$ & $\begin{array}{l}\text { Web-based } \\
\text { safety decision } \\
\text { aid (isafe) }\end{array}$ & $\begin{array}{l}\text { - RCT } \\
\text { - N= } 412 \\
\text { - 12-month follow- } \\
\text { up } \\
\text { - Intervention group: } \\
\text { website with safety } \\
\text { priority setting, } \\
\text { danger assessment } \\
\text { and individualized } \\
\text { feedback or tailored } \\
\text { action plan }\end{array}$ & $\begin{array}{l}\text { - Effective in } \\
\text { reducing violence } \\
\text { and depression } \\
\text { symptoms in } \\
\text { indigenous Māori } \\
\text { women. }\end{array}$ \\
\hline $\begin{array}{l}\text { McFarlane et } \\
\text { al. } \\
(2004)(48)\end{array}$ & USA & $\begin{array}{l}\text { Increasing safety- } \\
\text { promoting } \\
\text { behavior in } \\
\text { abused woman }\end{array}$ & $\begin{array}{l}\text { Telephone } \\
\text { intervention }\end{array}$ & $\begin{array}{l}\text { - Experimental } \\
\text { study } \\
\text { - N=150 } \\
\text { - Intervention group: } \\
\text { received the usual } \\
\text { services and } 6 \\
\text { telephone calls } \\
\text { - Data gathering: at } \\
3,6,12 \text {, and } 18 \\
\text { months }\end{array}$ & $\begin{array}{l}\text { - Increasing } \\
\text { safety-promoting } \\
\text { behavior in } \\
\text { intervention group }\end{array}$ \\
\hline $\begin{array}{l}\text { Thomas et al. } \\
(2005)(49)\end{array}$ & USA & $\begin{array}{l}\text { Assessing } \\
\text { effectiveness of } \\
\text { a telemedicine } \\
\text { program }\end{array}$ & $\begin{array}{l}\text { Telemedicine } \\
\text { program } \\
\text { (teleconference } \\
\text { sessions) }\end{array}$ & $\begin{array}{l}\text { - Semi-experimental } \\
\text { study } \\
\text { - N: } 38 \\
\text { - teleconference } \\
\text { sessions with } \\
\text { telephone and } \\
\text { facsimile contact } \\
\text { - Number of } \\
\text { session: } 3 \text { in the 4- } \\
6 \text { weeks }\end{array}$ & $\begin{array}{l}\text { - Good } \\
\text { performance on } \\
\text { screening, } \\
\text { treatment and } \\
\text { referral }\end{array}$ \\
\hline
\end{tabular}

IPV: Intimate Partner Violence

RCT: Randomized-Controlled Trial

TTS: Telephone Support Services

In the next stage 4 level of SEM was surveyed. In result four dimensions of violence against women and children and IT-based interventions were investigated. The four levels of individual, relationship, community and societal for woman \& child was described. Then a comprehensive model in this field was presented.

\section{Individual (Woman \& Child) Level:}

Individual level factors include age, level of education, history of alcohol use, history of violence and marriage at a younger age (50). Young age in marriage leads to increased exposure to violence due the husband is superior to the women (51). These risk factors had a greater impact during the Covid-19 pandemic (27). Web-Based safety decision 
was effective in reducing violence and depression symptoms (47). Long periods of Covid-19 quarantine have been associated with post-traumatic symptoms Stress Disorder (PTSD), anxiety, anger and boredom (52). Online interventions at the individual level of violence against women and children increased during the Covid-19 era (53). Remote counseling provides fair access to psychological support for children (29).

Online interventions are one of the effective methods (54). Health care professionals need to be aware of all the demographic, psychological and psychological histories of the injured woman and children for supporting, especially during a pandemic (27). Clinical decision support systems for child abuse are effective in improving the decisions of practitioners and physicians (55). Integration of child abuse screening system with electronic health record in a large health care network can increase the possibility of recording reports of children exposed to violence (56).

Development of an interpersonal-violence registry system (IPVRS) is an effective approach to tackle violence. Recording, evaluating and monitoring risk factors, especially alcohol consumption, is very helpful in supporting vulnerable people and prioritizing policies. The geographical distribution of vulnerable people based on health habits and other risk factors can be identified using the registry. Social and economic indicators are also recorded and analyzed. Barriers to accessing care services can also be addressed through the registry system. International classification systems support the systematic recording of information in the registry system. The place and time of the violence occurred, manner and frequency of the violence can be traced through international classification systems. The number and type of services provided, the name and type of service provider and the specific outcome of the services provided can be monitored (57). ICD11 as international classification includes criteria for intimate partner violence, neglect and child abuse and neglect (58) and ICD-11 online interface to find and search the classification codes of disorders (58).

Covid-19 pandemic had a significant impact on child abuse and neglect (CAN)(59). Online education and gamification can be used for empowering of children and psychological support (60).

\section{Relationship Level:}

This level relates to a person's closest friends, partners and family, and marital family issues can affect them. The three dimensions of this level are: multiple partners, arranged or forced marriages relationship satisfaction and marital conflict. Communication skills training programs focusing on culturally appropriate conflict management should be designed for couples (50). Experts and health care providers have identified several benefits of using remote support, such as dealing with isolation, reducing deterrence, fear and embarrassment, and enhancing victims' empowerment (3). Gender equity in household is critical issue (61) and analyzing of status of high risk can be used for effective procedure.

Due to social distance, vulnerable people cannot improve their communication under psychological support primary care physicians, professors, friends or family. It also reduces the motivation for these people to seek professional help digital communications can be the key solution (27). Social support and having social capital is a key factor for vulnerable population. In some cases, social distance may prevent social support. Social support was affected during the pandemic due to limited resources and social distance. While social support is very effective in improving mood. Also access to social resources depends on the economic situation of women (27)

\section{Community Level:}

The three dimensions of this level are: poverty, social support and employment opportunities (50). Reducing court access to legal protections, reducing face-to-face support sessions and physician attention, access to essential 
services such as access to affordable emergency housing, and seeking help are some of the challenges of the pandemic era. Supportive childcare is reduced and the economic burden as well as the opportunity to escape abuse is increased. During this period, the use of rape crisis centers, domestic violence shelters, and other social organizations and free resources became more limited. Remote service based on priority can be one of the solutions (27). Sheltering policies based on priority are important at this level (50).

Education and empowerment increase access to resources in society, increase self-confidence, and improve highincome employment for women. Economic dependence increases the risk of violence and economic opportunities need to be created to increase employment status of women living in rural areas. (50). Online interventions for empowering is a key solutions (62). Fair resource access to all affected caregivers is an significant issue (27).

\section{Societal Level:}

There are four items at this level: Men's superiority and dominance over women, acceptance of violence, cultural practices and Laws \& policies (50).

The current US recession is a threat during the Covid-19 era and will continue after the pandemic. Economic stress increases for vulnerable people whose incomes are declining or who are unemployed (27). In addition to economic conditions, the closure of kindergartens and schools has affected women and have more internal responsibilities than men in domestic relationships (63). Risk of sexual abuse due to financial instability and less access to essential resources increase (64).

One of the important issues is to identify the cultural dimensions associated with the intimate partner abuse (65). Identifying the cultural and contextual research factors in the field of violence is essential. An interpersonal-violence registry system can be effective in collecting and analyzing information and prioritizing in this field (57). Improving children's social skills through IT-based interventions can be effective in preventing violence (61).

\section{Recommended Framework:}

IT-based interventions were reviewed in these 4 phases based on SEM model (figure1). IT tools based on evidencebased method in the four level was described. IT tools of individual level includes these items: violence registration system, smartphone, SMS Reminder, social media, websites and portal, e-mail, video conferencing, tele -consultation technology, Global Positioning System (GPS), GIS and wearable tracking device. IT tools of relationship level includes: violence registration system, smartphone, SMS Reminder, social media, websites and portal, E-mail, video conferencing and Tele -consultation technology. IT tools of community and social level includes: smartphone, SMS reminder, social media, websites and portal, national and international non-governmental organization (NGO) network, E-mail, video conferencing, Tele - consultation technology, screening information system, electronic health record, clinical decision support system, intelligent system/deep learning/machine learning, data mining, ICD-11 Online and E-dashboard (Figure 1). Tasks of 4 stakeholders in the field of violence against women and children and their areas of responsibility were presented with the help of IT-based interventions (Figure 2). Table 3 presents six recommendation for violence management and IT-based solutions. Finally, integrated information technology model presented for responses to violence against women and child during Covid-19 pandemic (Figure 3). The first and second levels of this model include 4 dimensions of SEM and 6 types of violence. The third level includes suggestions for managing violence and the fourth level includes IT-based interventions. Surveillance system and information resource system can be used for monitoring (Figure 3).

Table 3: Six recommendation for violence management and IT solutions

Page $13 / 23$ 
Recommendations

Detecting high risk individuals

\section{IT Solutions}

-Identifying high risk individuals via electronic health record by age, level of education, habits, history of alcohol use, history of violence, marriage at a younger age, physical and mental status/personality disorder

- Identification of child abuse via registry system and emergency alert system

- Child abuse clinical decision support integrated with Electronic Health Record for detecting

- Tele-triage of vulnerable Individuals

- Predictors of violence against children and machine learning method

Tracing and tracking

- Wearable tracking device for vulnerable individuals with disability

- GPS and GIS tracking device for vulnerable individuals with disability

Empowering

of vulnerable individuals and health care

providers

- Training of health care providers by e-guidelines, pathways and decision support system for violence management

- Access to demographic, physical and psychological information of vulnerable individuals for awareness of health care professionals

- Improving children's social skills through educational portals

- Mobile health-based platforms for training of parent and children

- Improving self-management and self-esteem efficacy via tele-consultation programs

- Promoting knowledge, attitude and practices via web based portal, mobile application, social media and motor engine

- Training on reporting IPV cases by health care providers

Legal \& Economic

Support

- Automated court access

- Sheltering policies based on priority by IPVRS reporting

- Virtual entrepreneurship

Access to health care services

- Determination of violence severity via DSS and intelligence system

- Fair resource access by reporting of IPVRS and public information system

Social and Mental Support

- Improving Social skill for vulnerable individuals by online campaigns.

- Supporting of post-traumatic symptoms Stress Disorder (PTSD), anxiety, anger and boredom, depression symptoms via digital communication

-Intelligence place-based emergency services

- Online education and gamification

- Tele consultation by Risk of sexual abuse

Governance \&

Management
- Evidence based decision making via IPVRS and public health system

- Allocation of resources and service management based on priority by e-dashboard

- Establishment of policy and legislation by reporting of public information system

- Gender equity in household 
The finalized framework for application IT-based interventions in the management of violence against women and children presented in 4 dimension including individual, relationship, community and societal. In this study, after reviewing the eligible articles, as well as WHO and CDC websites, E-health framework were compiled in four dimension.

\section{Discussion}

The integrated electronic health record accelerates the possibility of accurate triage by accessing the comprehensive information of the invulnerable children. Decision support system allows physicians and nurses to review and analyze diagnostic and triage guidelines (55). Intelligence tools are used to train caregivers, especially in the field of public health. Big data analysis increases the possibility of cost-effective preventive interventions in the field of child violence (61). In the proposed model, machine learning interventions and decision support system are considered. Risk assessment and modeling of determinants can be used for selecting best intervention. Mobile health-based platforms increases access to psychiatric services for children and families (61). Predictors of violence against children in the field of negligence can be surveyed $(66,67)$.

The use of IT-based approaches to support people that affected by social problems has increased during the Covid-19 epidemic. For example, one study conducted to determine the type of support victims of violence against women and domestic violence (VAWDV) by the support professionals in the Portuguese during the COVID-19 pandemic. The result presented that the telephone was most common tool to provide support services (3). In this study, smartphones as IT solutions was considered.

The Veteran's Health Administration (VHA) developed Intimate Partner Violence Assistance Program (IPVAP) that present IPV support and prevention services to veterans, their partners, and affected employees. In this program, affected women supported by through Strengths and Empowerment (RISE), that is patient-centered, evidence-based and trauma-informed brief counseling intervention (68). The study of Slupska et al. confirmed that safety-planning application named "myPlan can lead to empowering IPV survivors (62).

Social media are used as a platform for sharing the experiences of affected women, Hearing the voices of injured women, introducing supporting organization \& services, documenting rape cases and the function of justice system in dealing with these cases in different cultures (69). On the other hand, misuse and anonymity in social media leads to the spread of false culture, changing sexist attitudes and offline behavior, and greater hostile sexism (70). One of the main challenges of telehealth for women experiencing IPV is the privacy and security, which leads to limitations in its acceptance by the court houses and some agencies (68). In the section of policies and legislation in the presented model, this axis has been considered.

In some studies, the purpose of the intervention was to help care providers for rapid decision-making especially in emergencies. A technology for further acceptability must evidence-based, easy to use, user-friendly requires less time and provide a quick solution (34). It should be noted that the results of all studies did not confirm the effectiveness of the system, in some studies, no significant difference was observed between the intervention and control groups (35, $38,43)$.Health care providers should also receive training in identifying and reporting cases of domestic violence or child abuse and neglect (8), And IT tools can be used to improve this .

To measure the effectiveness of IT based interventions in this field requires further studies with large sample sizes. The key to successful use of a technology is the support of senior executives and all stakeholders. Also users of these tools should have internet literacy and access to the necessary resources and infrastructures (35). Adequate knowledge is very important when using these technologies by support service providers and victims and their 
families. Therapists must receive the necessary training to provide services and intervention (41). Reporting IPV cases by health care providers is also important. In this context, this was considered.

\section{Conclusions}

Managing violence against children and women during the Covid-19 period is one of the key issues. Social isolation and physical absence increase the conditions for child abuse and violence against women. Domestic violence and economic pressures increased, and vulnerable women and children were at greater risk. It is significant issue to identify people at risk, to follow and monitor them, to raise the awareness and knowledge of these people, and to empower and provide psychosocial support to these people during this period. In this study, a comprehensive review of IT-based interventions was presented and finally an international framework in this field was described.

\section{Declarations}

\section{Ethics approval and consent to participate}

Not applicable

\section{Consent for publication}

Not applicable

\section{Availability of data and materials}

Not applicable. Data sharing is not applicable to this article as no datasets were generated or analyzed during the current study.

\section{Competing interests}

No conflict of interest declared.

\section{Funding}

This study was funded with the authors' own contributions.

\section{Authors' contributions}

Elham Masert: Design, Gathering data, Analysis and Interpretation of data, Article writing

Zeinab Mohammadzadeh: Design, Gathering data, Analysis and interpretation of data, Article writing

\section{Acknowledgements}

We thank the social workers of the Health Determinants Research Center for their valuable advice.

\section{References}

1. Organization WH. Violence against women prevalence estimates, 2018: global, regional and national prevalence estimates for intimate partner violence against women and global and regional prevalence estimates for nonpartner sexual violence against women. 2021. 
2. Breiding M, Basile KC, Smith SG, Black MC, Mahendra RR. Intimate partner violence surveillance: Uniform definitions and recommended data elements. Version 2.0. 2015.

3. Caridade SMM, Saavedra R, Ribeiro R, Oliveira AC, Santos M, Almeida IS, et al. Remote support to victims of violence against women and domestic violence during the COVID-19 pandemic. The Journal of Adult Protection. 2021.

4. Organization WH. Addressing human rights as key to the COVID-19: response, 21 April 2020. World Health Organization; 2020.

5. Roesch E, Amin A, Gupta J, García-Moreno C. Violence against women during covid-19 pandemic restrictions. British Medical Journal Publishing Group; 2020.

6. Katz C, Fallon B. Protecting children from maltreatment during COVID-19: Struggling to see children and their families through the lockdowns. Child Abuse \& Neglect. 2021.

7. Taub A. A new Covid-19 crisis: Domestic abuse rises worldwide. The New York Times. 2020;6.

8. https://www. who ...

9. Hillis S, Mercy J, Amobi A, Kress H. Global prevalence of past-year violence against children: a systematic review and minimum estimates. Pediatrics. 2016;137(3).

10. Thomas EY, Anurudran A, Robb K, Burke TF. Spotlight on child abuse and neglect response in the time of COVID19. The lancet public health. 2020;5(7):e371.

11. Widom CS. Longterm consequences of child maltreatment. Handbook of child maltreatment: Springer; 2014. p. 225-47.

12. Maserat E, Keikha L, Davoodi S, Mohammadzadeh Z. E-health roadmap for COVID-19 vaccine coverage in Iran. BMC Public Health. 2021;21(1):1-11.

13. Gandhi M, Yokoe DS, Havlir DV. Asymptomatic transmission, the Achilles' heel of current strategies to control Covid-19. Mass Medical Soc; 2020.

14. Simon MA. Responding to Intimate Partner Violence During Telehealth Clinical Encounters. JAMA. 2021;325(22):2307-8.

15. Racine N, Hartwick C, Collin-Vézina D, Madigan S. Telemental health for child trauma treatment during and postCOVID-19: Limitations and considerations. Child Abuse \& Neglect. 2020;110:104698.

16. Dursun OB, Turan B, Pakyürek M, Tekin A. Integrating telepsychiatric services into the conventional systems for psychiatric support to health care workers and their children during COVID-19 pandemics: results from a national experience. Telemedicine and e-Health. 2021;27(3):269-75.

17. Organization WH. Strengthening health systems to respond to women subjected to intimate partner violence or sexual violence: a manual for health managers. 2017.

18. Organization WH. Health care for women subjected to intimate partner violence or sexual violence: A clinical handbook. World Health Organization; 2014.

19. Katz C, Fallon B. Protecting children from maltreatment during COVID-19. Child abuse \& neglect. 2020;110:104753.

20. Organization WH. Responding to intimate partner violence and sexual violence against women: WHO clinical and policy guidelines: World Health Organization; 2013.

21. Bradley NL, DiPasquale AM, Dillabough K, Schneider PS. Health care practitioners' responsibility to address intimate partner violence related to the COVID-19 pandemic. Cmaj. 2020;192(22):E609-E10. 
22. Kimber M, McTavish JR, Vanstone M, Stewart DE, MacMillan HL. Child maltreatment online education for healthcare and social service providers: Implications for the COVID-19 context and beyond. Child Abuse \& Neglect. 2021;116:104743.

23. Jack SM, Munro-Kramer ML, Williams JR, Schminkey D, Tomlinson E, Jennings Mayo-Wilson L, et al. Recognising and responding to intimate partner violence using telehealth: Practical guidance for nurses and midwives. Journal of clinical nursing. 2021;30(3-4):588-602.

24. Gloff NE, LeNoue SR, Novins DK, Myers K. Telemental health for children and adolescents. International Review of Psychiatry. 2015;27(6):513-24.

25. Ros-DeMarize R, ChungMD P, StewartPhD R. Pediatric behavioral telehealth in the age of COVID-19: Brief evidence review and practice considerations. Current Problems in Pediatric and Adolescent Health Care. 2021:100949.

26. Walters AS. 10 months in: Telemental health for children and adolescents during the COVID-19 pandemic. The Brown University Child and Adolescent Behavior Letter. 2021;37(2):8-.

27. Rieger A, Blackburn AM, Bystrynski JB, Garthe RC, Allen NE. The impact of the COVID-19 pandemic on genderbased violence in the United States: Framework and policy recommendations. Psychological trauma: theory, research, practice, and policy. 2021.

28. Biswas M, Mould D, Khan Y, Kapil N. Applying a Social-Ecological Approach to Institutionalise C4D Curriculum and Research. The Journal of Development Communication. 2021;32(1):108-20.

29. Obikane E, Baba T, Shinozaki T, Obata S, Nakanishi S, Murata C, et al. Internet-based behavioural activation to improve depressive symptoms and prevent child abuse in postnatal women (SmartMama): a protocol for a pragmatic randomized controlled trial. BMC pregnancy and childbirth. 2021;21(1):1-11.

30. Gülırmak K, Orak OS. Effectiveness of web-based distance education for parents in the prevention of emotional neglect and abuse: A randomized controlled study. Perspectives in Psychiatric Care. 2021;57(2):573-82.

31. Traube DE, Hsiao H-Y, Rau A, Hunt-O’Brien D, Lu L, Islam N. Advancing home based parenting programs through the use of telehealth technology. Journal of Child and Family Studies. 2020;29(1):44-53.

32. Fogler JM, Normand S, O'Dea N, Mautone JA, Featherston M, Power TJ, et al. Implementing Group Parent Training in Telepsychology: Lessons Learned During the COVID-19 Pandemic. Journal of Pediatric Psychology. 2020;45(9):983-9.

33. Stewart RW, Orengo-Aguayo R, Young J, Wallace MM, Cohen JA, Mannarino AP, et al. Feasibility and effectiveness of a telehealth service delivery model for treating childhood posttraumatic stress: A community-based, open pilot trial of trauma-focused cognitive-behavioral therapy. Journal of Psychotherapy Integration. 2020;30(2):274.

34. Luo S, Botash AS. Testing a mobile app for child abuse treatment: A mixed methods study. International journal of nursing sciences. 2020;7(3):320-9.

35. van Rosmalen-Nooijens K, Wong SLF, Prins J, Lagro-Janssen T. Young People, Adult Worries: Randomized Controlled Trial and Feasibility Study of the Internet-Based Self-Support Method "Feel the ViBe" for Adolescents and Young Adults Exposed to Family Violence. Journal of medical internet research. 2017;19(6):e204.

36. Investigators E. Novel educational program improves readiness to manage intimate partner violence within the fracture clinic: A pretest-posttest study. CMAJ open. 2018;6(4):E628.

37. Walsh WA, Meunier-Sham J, Re C. Using Telehealth for Sexual Assault Forensic Examinations: A Process Evaluation of a National Pilot Project. Journal of Forensic Nursing. 2019;15(3):152-62.

38. Hegarty K, Tarzia L, Valpied J, Murray E, Humphreys C, Taft A, et al. An online healthy relationship tool and safety decision aid for women experiencing intimate partner violence (I-DECIDE): a randomised controlled trial. The Lancet Public Health. 2019;4(6):e301-e10.

Page 18/23 
39. Sabri B, Njie-Carr VP, Messing JT, Glass N, Brockie T, Hanson G, et al. The weWomen and ourCircle randomized controlled trial protocol: a web-based intervention for immigrant, refugee and indigenous women with intimate partner violence experiences. Contemporary clinical trials. 2019;76:79-84.

40. Ford-Gilboe M, Varcoe C, Scott-Storey K, Wuest J, Case J, Currie LM, et al. A tailored online safety and health intervention for women experiencing intimate partner violence: the iCAN Plan 4 Safety randomized controlled trial protocol. BMC Public Health. 2017;17(1):1-12.

41. Steinmetz S, Gray MJ. Treating emotional consequences of sexual assault and domestic violence via telehealth. Career Paths in Telemental Health: Springer; 2017. p. 139-49.

42. Constantino RE, Braxter B, Ren D, Burroughs JD, Doswell WM, Wu L, et al. Comparing online with face-to-face HELPP intervention in women experiencing intimate partner violence. Issues in mental health nursing. 2015;36(6):430-8.

43. Stevens J, Scribano PV, Marshall J, Nadkarni R, Hayes J, Kelleher KJ. A Trial of Telephone Support Services to Prevent Further Intimate Partner Violence. Violence Against Women. 2015;21(12):1528-47.

44. Saftlas AF, Harland KK, Wallis AB, Cavanaugh J, Dickey P, Peek-Asa C. Motivational interviewing and intimate partner violence: a randomized trial. Annals of epidemiology. 2014;24(2):144-50.

45. Tiwari A, Yuk H, Pang P, Fong D, Yuen F, Humphreys J, et al. Telephone intervention to improve the mental health of community-dwelling women abused by their intimate partners: a randomised controlled trial. Hong Kong medical journal= Xianggang yi xue za zhi. 2012;18:14-7.

46. Tiwari A, Fong DYT, Yuen KH, Yuk H, Pang P, Humphreys J, et al. Effect of an advocacy intervention on mental health in Chinese women survivors of intimate partner violence: a randomized controlled trial. Jama. 2010;304(5):536-43.

47. Koziol-McLain J, Vandal AC, Wilson D, Nada-Raja S, Dobbs T, McLean C, et al. Efficacy of a web-based safety decision aid for women experiencing intimate partner violence: randomized controlled trial. Journal of medical Internet research. 2018;20(1):e8.

48. McFarlane J, Malecha A, Gist J, Watson K, Batten E, Hall I, et al. Increasing the Safety-Promoting Behaviors of Abused Women: In this study, a telephone intervention for victims of intimate-partner violence showed efficacy for 18 months. AJN The American Journal of Nursing. 2004;104(3):40-50.

49. Thomas CR, Miller G, Hartshorn JC, Speck NC, Walker G. Telepsychiatry program for rural victims of domestic violence. Telemedicine Journal \& e-Health. 2005;11(5):567-73.

50. Tekkas Kerman K, Betrus P. Violence against women in Turkey: A social ecological framework of determinants and prevention strategies. Trauma, Violence, \& Abuse. 2020;21(3):510-26.

51. Yüksel-Kaptanoğlu İ, Türkyılmaz AS, Heise L. What puts women at risk of violence from their husbands? Findings from a large, nationally representative survey in Turkey. Journal of interpersonal violence. 2012;27(14):2743-69.

52. Brooks SK, Webster RK, Smith LE, Woodland L, Wessely S, Greenberg N, et al. The psychological impact of quarantine and how to reduce it: rapid review of the evidence. The lancet. 2020;395(10227):912-20.

53. Kannarkat JT, Smith NN, McLeod-Bryant SA. Mobilization of Telepsychiatry in Response to COVID-19-Moving Toward 21 st Century Access to Care. Administration and Policy in Mental Health and Mental Health Services Research. 2020;47(4):489-91.

54. Blackburn AM, Goetter EM. Treatment of anxiety disorders in the digital age. Clinical Handbook of Anxiety Disorders: Springer; 2020. p. 297-313.

55. McGinn T, Feldstein DA, Barata I, Heineman E, Ross J, Kaplan D, et al. Dissemination of child abuse clinical decision support: moving beyond a single electronic health record. International journal of medical informatics. 
2021;147:104349.

56. Rumball-Smith J, Fromkin J, Rosenthal B, Shane D, Skrbin J, Bimber T, et al. Implementation of routine electronic health record-based child abuse screening in General Emergency Departments. Child abuse \& neglect. 2018;85:58-67.

57. lezadi S, Alizadeh M, Samadirad B, Khanijahani A, Pourasghari H, Sadeghi-Bazargani H, et al. A qualitative study on the establishment of an interpersonal violence registry system in Iran. Journal of interpersonal violence. 2020:0886260520978181.

58. Heyman RE, Snarr JD, Slep AMS, Baucom KJ, Linkh DJ. Self-reporting DSM-5/ICD-11 clinically significant intimate partner violence and child abuse: Convergent and response process validity. Journal of family psychology. 2020;34(1):101.

59. Nguyen LH. Calculating the impact of COVID-19 pandemic on child abuse and neglect in the US. Child Abuse \& Neglect. 2021:105136.

60. Ghosh R, Dubey MJ, Chatterjee S, Dubey S. Impact of COVID-19 on children: special focus on the psychosocial aspect. Minerva Pediatrica. 2020;72(3):226-35.

61. Hunt X, Tomlinson M, Sikander S, Skeen S, Marlow M, du Toit S, et al. Artificial Intelligence, Big Data, and mHealth: The Frontiers of the Prevention of Violence Against Children. Frontiers in artificial intelligence. 2020;3:80.

62. Slupska J, Lindsay Brown M. Aiding Intimate Violence Survivors in Lockdown: Lessons about Digital Security in the COVID-19 Pandemic. Available at SSRN 3897863. 2021.

63. Alon T, Doepke M, Olmstead-Rumsey J, Tertilt M. The impact of COVID-19 on gender equality. National Bureau of economic research; 2020.

64. Klatt T, Cavner D, Egan V. Rationalising predictors of child sexual exploitation and sex-trading. Child Abuse \& Neglect. 2014;38(2):252-60.

65. Kasturirangan A, Krishnan S, Riger S. The impact of culture and minority status on women's experience of domestic violence. Trauma, Violence, \& Abuse. 2004;5(4):318-32.

66. Seddighi H, Salmani I, Javadi MH, Seddighi S. Child abuse in natural disasters and conflicts: a systematic review. Trauma, Violence, \& Abuse. 2021;22(1):176-85.

67. Abdel-Fatah NA. Determinants of severe physical disciplinary practices against children in Egypt. Child Abuse \& Neglect. 2021;111:104821.

68. Rossi FS, Shankar M, Buckholdt K, Bailey Y, Israni ST, Iverson KM. Trying times and trying out solutions: intimate partner violence screening and support for women veterans during COVID-19. Journal of general internal medicine. 2020;35(9):2728-31.

69. Kosloski AE, Diamond-Welch BK, Mann O. The presence of rape myths in the virtual world: A qualitative textual analysis of the Steubenville sexual assault case. Violence and gender. 2018;5(3):166-73.

70. Fox J, Cruz C, Lee JY. Perpetuating online sexism offline: Anonymity, interactivity, and the effects of sexist hashtags on social media. Computers in Human Behavior. 2015;52:436-42.

\section{Figures}




\section{IT Tools}

- Violence registration system

- Smartphone

- SMS Reminder

- Social media

- Websites and portal

- E-mail

- Video conferencing

- Tele -consultation technology

ology

IT Tools

- Violence registration system

- Smartphone

- SMS Reminder

- Social media

- Websites and portal

- E-mail

- Video conferencing

- Tele -consultation technology

- Wearable tracking device

- GPS, GIS

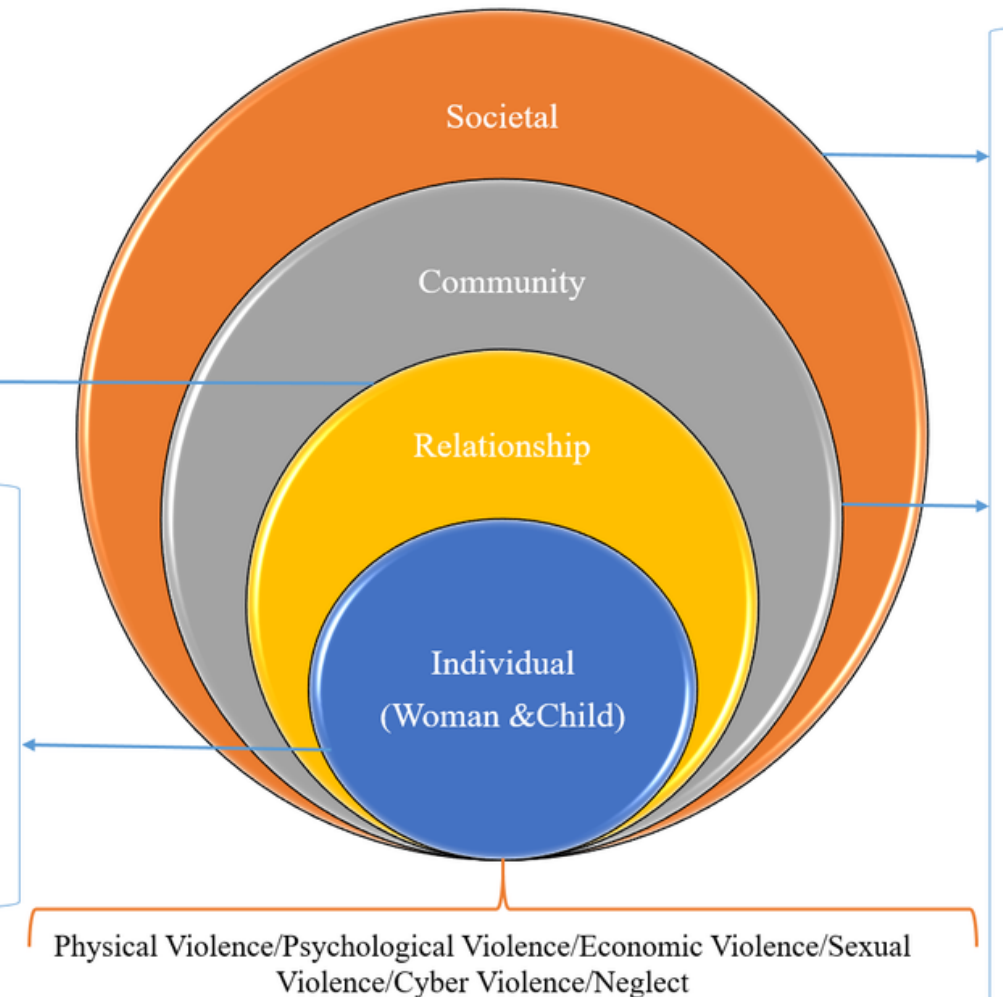

Violence/Cyber Violence/Neglect

\section{IT Tools}

- Smartphone

- $\quad$ SMS Reminder

- Social media

- Websites and portal

- National and International NGO Network

- E-mail

- Video conferencing

- Tele-consultation technology

- Screening information system

- Electronic Health Record

- Clinical decision support system

- Intelligent system/Deep learning/Machine Learning Data mining

- ICD-11 Online

- E-Doshboard

\section{Figure 1}

IT tools intervention in SEM levels 


\section{WHO and International Organization}

-Promote health literacy through social media and search engines

-Development of portals for social, economic and psychological support

-International classification of violence against women and children by ICD-11

-Exchange of experiences in the electronic platform

-International Tele-consultion program

-Scientific video-conferencing

\section{Ministry of Health and Health Policy}

Makers

-Decision-making based on registry

information system

-Development confidentiality and privacy rules

-Mental and social support by reporting of screening system

-Service prioritization by e-dashboard

-Analyze social networks to manage affairs

-Integrated expert system for services

management
Non-Govermental Organization

-Public information campaigns

- Culture Awareness by online meeting

- NGO Interaction Network by social networks and other communication channels

-Attract financial support with online advertising

-Virtual entrepreneurship of vulnerable woman

-Empowerment through virtual networks

\section{Heath Care Organization}

/Court/University/ Researcher

-Improving Health Literacy

- Development R\&D projects

-Online access to care services for vulnerable children

-Monitor children's group electronic games

-Promote knowledge and awareness

through e-counseling and group training programs

-Legal support by electronic health record

\section{Figure 2}

Stockholders of violence management \& IT intervention 


\section{Governance \& Management}

\section{Level of SEM}

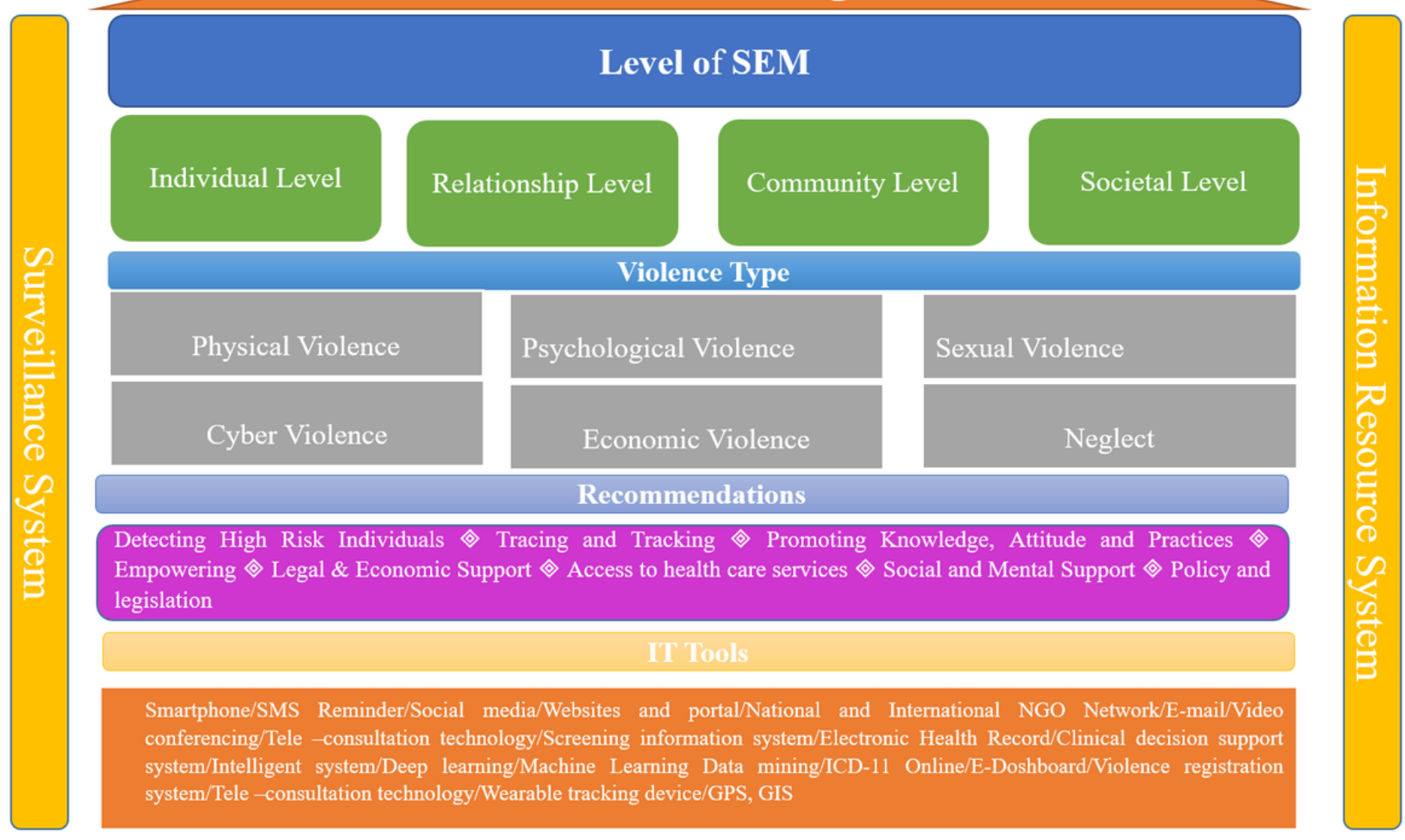

\section{Figure 3}

Model of violence management \& IT response 